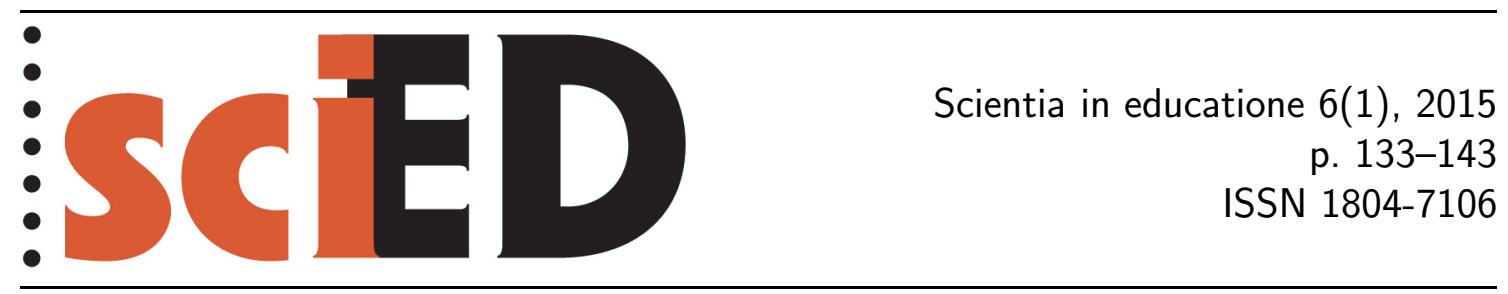

\title{
Hodnotenie zručností v bádatel'sky orientovanej výučbe biológie
}

\author{
Ivana Slepáková, Katarína Kimáková
}

\begin{abstract}
Abstrakt
Medzinárodný projekt 7RP ESTABLISH bol zameraný na vývoj metodických materiálov pre širšie uplatnenie výučby aj prírodných vied založenej na bádaní (IBSE - Inquiry Based Science Education). Na ich tvorbe a implementácii do výučby sa podielalo 11 partnerov. Na Slovensku bolo do pilotného projektu zapojených viac než 40 učitelov biológie, chémie a fyziky ZS̆ a SS̆. Skúsenosti z projektu ESTABLISH ukázali, že učitelia mali pri implementácii IBSE pocit straty kontroly nad vyučovaním, pretože nevedeli ako identifikovat a hodnotit rozvoj bádatelských zručností žiakov. Chýbajú vhodné nástroje, ktoré by učitelom v tomto procese pomohli. Tvorbe nástrojov sa venuje nadväzujúci projekt 7RP SAILS. Učitelia, ktorí overujú IBSE v praxi, sa zúčastňujú prípravného vzdelávania zameraného aj na hodnotenie. Partneri v projekte SAILS vychádzajú pri tvorbe metodík z ich praktických skúseností. V príspevku je uvedený konkrétny príklad hodnotiaceho nástroja vytvoreného na základe prípadových štúdií z výučby prírodovedných predmetov. Prípadové štúdie z projektu SAILS prispeli k formovaniu všeobecnejšieho postupu tvorby kritérií formatívneho a následne sumatívneho hodnotenia žiackeho bádania. Prvým krokom je selekcia konkrétnej zručnosti, ktorú chce učitel' sledovat, a definovanie nevyhnutného základu, ktorý sa dalej rozvíja, upevňuje a rozširuje. Učitel poskytuje priebežne spätnú väzbu žiakovi formou dialógu o tom, v ktorej fáze zvládania zručnosti sa nachádza a na čom musí v d’alšom kroku pracovat. Podklad pre sumatívne hodnotenie žiaka predstavuje najvyšší stupeň danej zručnosti, ktorú dosiahol za hodnotené obdobie.
\end{abstract}

Klíčová slova: formatívne hodnotenie, sumatívne hodnotenie, bádatelské zručnosti, spätná väzba.

\section{Assessment of Skills in Inquiry Based Biology Education}

\begin{abstract}
International project FP7 ESTABLISH was focused on the development of methodological materials for wider use of inquiry based education (IBSE - Inquiry Based Science Education). Eleven partners participated in the creation and implementation of these materials in teaching. In Slovakia, the pilot project involved 40 teachers of biology, chemistry and physics at lower and higher secondary schools. It transpired that the teachers felt loss of control over teaching IBSE because they did not know how to identify and assess the
\end{abstract}


development of pupils' inquiry skills. There is a lack of appropriate instruments, which could help teachers in this process. The preparation of assessment tools of inquiry skills in IBSE is done within project SAILS FP7. Teachers who trial IBSE in practice participate in preparatory training focused on assessment. The creation of methods in SAILS project is based on their practical experience. The paper presents a concrete example of the assessment tool created on the basis of case studies of science teaching practise. Case studies of SAILS project contribute to shaping a more general procedure of formative and also summative assessment of pupils' inquiry. The first step is the selection of a particular skill the teacher wants to assess and also the definition of the essential foundation, which is further developed, consolidated and expanded. The teacher provides continuous feedback to the pupil in a dialogue about how his/her skills develop and what he/she should work on. The basis for summative assessment of the pupil represents the highest level of the skills he/she achieved during the assessment period.

Key words: formative assessment, summative assessment, inquiry skills, feedback.

\section{SÚČASNÝ STAV PRÍRODOVEDNÉHO VZDELÁVANIA}

\section{A JEHO SMEROVANIE}

Neustály rozvoj technológií a modernizácia životného štýlu ovplyvňujú vývoj všetkých oblastí v súčasnom svete. Preto aj v didaktikách prírodovedných predmetov je $\mathrm{v}$ súčasnosti nevyhnutná zmena $\mathrm{v}$ príprave študentov, $\mathrm{z}$ ktorých je potrebné vyformovat úspešné osobnosti zajtrajška očakávané na pracovnom trhu, teda všestranné vytrvalé individuality schopné riešit s nadhladom problémové situácie. Prírodovedné vzdelávanie môže poskytnút študentom možnost̉ rozvíjat všeobecné bádatel’ské schopnosti, získat špecifické zručnosti pre vlastné objavovanie a pochopit’ prírodovedné pojmy a princípy (Edelson, Gordin \& Pea, 1999).

Slovensko sa ocitlo pod priemerom v štúdiách PISA, nielen v oblasti prírodovedných kompetencií, ale aj v riešení problémových situácií. Slovenskí žiaci sú druhí najmenej vytrvalí spomedzi testovaných krajín, pričom index vytrvalosti žiakov vyjadruje ochotu riešit zložité problémy (Šiškovič \& Toman, 2014). Zvýšit pocit istoty riešit problém sa dá častejším stretom žiaka s problémom, aby rozvíjal schopnost’ využívat získané vedomosti a spôsobilosti v každodennom živote.

Potreba zlepšit naše doterajšie podpriemerné výsledky v prírodovednej gramotnosti by mala upriamit pozornost́ didaktikov ako aj učitelov na také metódy, ktoré rozvíjajú kritické myslenie a spôsobilosti riešit problémy a dochádza pri nich k posunu podielu práce smerom k žiakovi, teda aktivizujú žiaka. Zaradenie praktických aktivít do tematického plánu učitel'a a ich samotná realizácia vytvára podmienky pre zmenu prístupu žiaka $\mathrm{k}$ výučbe alebo prehĺbenia vztahu k prírode a $\mathrm{k}$ prírodovednému predmetu. Tieto podmienky možno ešte posilnit zavádzaním bádatel'sky orientovaných úloh. V rámci viacerých projektov 7RP (Primas, ESTABLISH, Fibonacci) vznikli metodické materiály pre širšie uplatnenie výučby prírodných vied založenej na bádaní. Pod takto orientovanou výučbou sa rozumie prístup označovaný v anglickom jazyku ako IBSE (Inquiry-Based Science Education). Český ekvivalent tohto pojmu je „Badatelsky orientované vyučování so zaužívanou skratkou BOV (Papáček, 2010). V slovenskej literatúre sa stretávame aj s inými pojmami označujúcimi rovnaký koncept, napr. „výskumne ladená koncepcia prírodovedného vyučovania“" (Held et al., 2011).

V slovenských školách bojujú mnohí učitelia s nedostatočnou časovou dotáciou a mnohokrát aj materiálnou výbavou pre prírodovedné predmety vrátane biológie, čo 
ich môže čiastočne odrádzat’ od implementácie bádatelských aktivít, ktorých podstatou je vytvorenie priestoru pre aktívnu činnost žiaka. Mnohé bádatelsky orientované aktivity sú však časovo zvládnutel’né a na materiálne vybavenie nenáročné.

Učitel', ktorý sa usiluje zapojit žiakov do praktických aktivít, síce upúšta od časovo úspornej demonštrácie, ale žiakom zadáva úlohy, kde postupujú výlučne podla daných krokov, ba niekedy vopred poznajú aj výsledok. Zväčša tak nedochádza $\mathrm{k}$ rozvoju kritického myslenia ani spôsobilosti formulovat’ a riešit problém, a často ani samotný žiak nie je dostatočne motivovaný k lepšiemu výkonu. Priestorom pre zvyšovanie ochoty zapojit sa do vyučovacieho procesu a riešit problém je zavádzanie takých praktických úloh, pri ktorých žiak častejšie na problém narazí, potrebuje ho formulovat a navrhnút postup riešenia. Príkladom takýchto úloh sú bádatelsky orientované aktivity. Mnohé z týchto aktivít sú volne dostupné na internete ako výsledok spolupráce učitelov z viacerých krajín v rámci rôznych projektov. Samotní učitelia však nie sú pripravení po takomto materiáli siahnut. Implementácia IBSE do prírodovedných predmetov na Slovensku poukazuje na potrebu vzdelávania učitelov zameraného na širšie využite bádatelských metód výučby, na rozvoj prírodovednej gramotnosti, ako aj na hodnotenie bádatelských zručností a uplatnenia spätnej väzby pri hodnotení. Dlhodobým cielom by malo byt', aby kreatívny učitel' bol schopný samostatne vypracovat návrhy IBSE úloh a prispôsobit si kritériá hodnotenia zručností rozvíjaných v téme, ktorú práve vyučuje.

\section{IBSE - CESTA AKTIVIZÁCIE ŽIAKA}

Na zlepšenie pocitu istoty žiaka pri riešení problému je často využivané problémové vyučovanie predstavujúce velmi rozšírenú koncepciu vyučovania, ktorej snahou je rozvíjat tvorivé myslenie, tvorivé schopnosti žiakov a ich samostatnost'. Na rozdiel od obvyklých prístupov k výučbe, v ktorých učitelia navodia problém až po tom, čo žiaci získali relevantný obsah vedomostí a zručností pri koncepcii problémového vyučovania, sa žiaci učia už počas hladania riešenia problémov (Chin \& Chia, 2005). Ani pri tejto stratégii však žiaci nie sú vždy nútení formulovat predpoklad a hladat dôkazy pre fungovanie vlastných návrhov a riešení. Spätnú väzbu čakajú často od učitela, ktorý spravidla aj hned’ zhodnotí, či žiakom navrhované riešenie je správne alebo nesprávne. V bádatel'sky orientovanej výučbe by mali dôkazy správnosti hladat a nájst sami žiaci. Učast žiakov na bádaní podporuje potrebu klást’ otázky, navrhovat̉ hypotézy pre formovanie predpokladov, použitie nástrojov na zhromaždovanie a analýzu získaných dát, formulovat závery na základe empirických dôkazov, argumentovat', prezentovat svoje poznatky a použit široké spektrum rozumových stratégií, ktoré zahŕnajú kritické, kreatívne, kauzálne a logické myslenie (Olson \& Loucks-Horsley, 2000; Minstrell \& van Zee, 2000).

V konštruktivistických vyučovacích prístupoch vrátanie problémového vyučovania zohráva učitel' rolu sprievodcu a facilitátora žiaka vo vzdelávacom procese (Erdogan \& Senemoglu, 2014). Tak ako pedagógovia vedú žiakov, ako by mali riešit každodenné situácie, tak je potrebné žiakom ukázat̉ riešenie zložitejších problémov v širšom ponímaní. Ide o problémy, ktoré riešia vedci, aby nám zabezpečili pohodlnejší každodenný život. Teda ukázat žiakom ako pracuje vedec, ved' koniec koncov v prírodných vedách je bádanie prirodzené. Z tohto hladiska je pomerne dôležité poznat predstavu žiaka o práci vedca a o vedcovi samotnom. Žial', neexistujú informácie o tom, ako si súčasný žiak predstavuje „biológa“, a aj preto by mal byt v budúcnosti zameraný výskum na to, ako žiak vzhliada na učitela biológie, biológa 
profesionála a na vedca (Prokop et al., 2007). Čas učitela sa dá využit lepšie ako prerozprávaním textov z učebníc. Podla príručky Introduction to Formative Assessment (2006) skúsenosti a výskum poukazujú na to, že samotné učenie o „správnych“ vedeckých ideách nemusí nutne zmenit̉ porozumenie žiakov a je pravdepodobnejšie, že zmena nastane, ked’ si sami overia vlastné hypotézy.

Príprava učitel’a na realizáciu bádatel'skej aktivity vyžaduje istú dávku kreativity. Učitel’ by taktiež mal byt schopný analyzovat jednotlivé kroky bádatelského cyklu, ktorým žiaci pri bádaní prechádzajú a vopred určit, aký stupeň bádania bude aplikovate. Nižšie uvádzame 6 krokov bádatel'ského cyklu, ako ich podrobne popisuje vo svojej štúdii Llewellyn (2002). Realizácia bádatel’sky orientovanej výučby je založená na takých aktivitách, ktorých podstatou je prechádzanie jednotlivými krokmi bádatel’ského cyklu: 1 - identifikuj problém, 2 - formuluj predpoklad/hypotézu, 3 naplánuj postup/pokus na overenie predpokladu, 4 - realizuj prieskum/pokus, zhromaždi a spracuj údaje, 5 - odhal' súvislosti a formuluj záver, 6 - predstav výsledok ostatným a diskutujte o ňom. Z diskusie môže vzíst’ nový problém. Cyklus, pri ktorom študenti skúšajú postupovat ako vedci, je možné uskutočnit na viacerých úrovniach samostatnosti, ako uvádzame nižšie.

Na schéme (obr. 1), ktorú sme vytvorili prepojením bádatel'ského cyklu upraveného podla Llewellyna (2002) a stupňov bádania podla Wenninga (2005), môžeme vidiet', akou mierou je žiak zapojený do bádania. Pri bežných praktických aktivitách, kde nie je využitá metóda IBSE, umožňuje učitel žiakom realizáciu prevažne takých úloh, kde postupujú výlučne podla vopred daného návodu. IBSE vyžaduje interaktivitu, kde žiaci sú nútení pri I. stupni bádania logicky uvažovat, pri II. stupni zapojit aj praktické zručnosti, pri III. stupni samostatne plánovat́ postup, pri IV. stupni formulovat bádatel’ský problém viazaný určitou témou. Najvyšší V. stupeň, otvorené bádanie, umožňuje žiakom prechádzat’ všetkými krokmi bádatelského cyklu, pričom problém žiaci objavujú samostatne. Väčšinou je tento stupeň bádania realizovaný formou projektu.

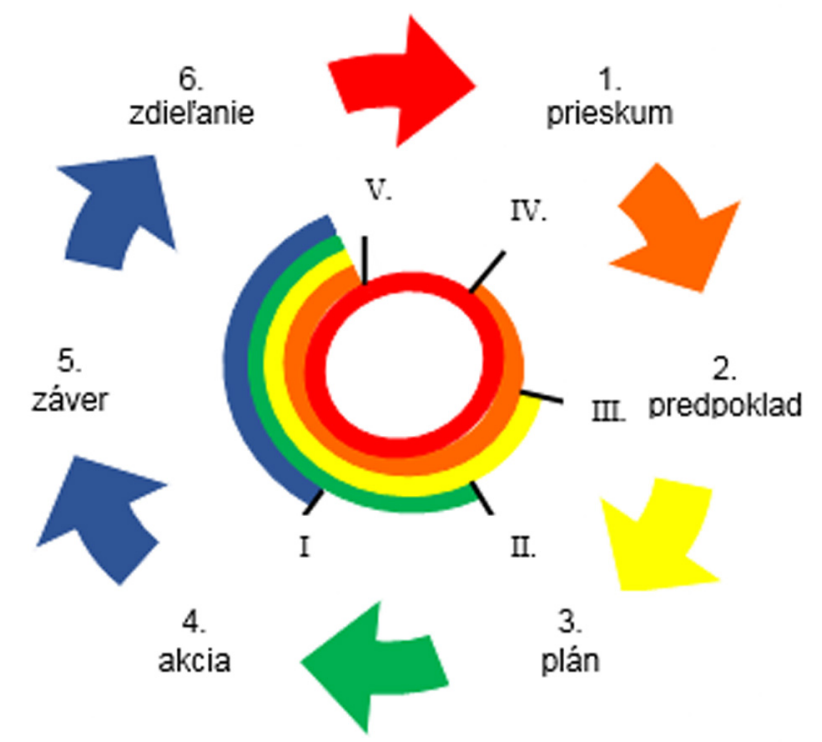

Obr. 1: Aktívne kroky bádatelského cyklu IBSE realizované žiakom (od prvého po šiesty) prepojené so stupňami bádania - I. Interaktívna demonštrácia, II. Riadené objavovanie, III. Riadené bádanie, IV. Viazané bádanie (na tému), V. Otvorené bádanie (Kimáková et al., 2014) 


\section{ImPLEMENTÁCIA A DiSEMINÁCIA IBSE}

Tak ako v mnohých iných krajinách, aj na Slovensku dochádza v posledných rokoch $\mathrm{k}$ zmene spôsobu výučby smerom k aktivizácii žiakov v edukačnom procese. Jednou z možností, ako zvýšit zapojenost žiaka do vyučovania a jeho aktívny prístup k vzdelávaniu, je zavádzanie aktivizujúcich metód a nových prístupov vo vzdelávaní prírodovedných predmetov. Tvorbou, pilotovaním, implemetáciou a samotnou disemináciou týchto spôsobov výučby sa zaoberá množstvo medzinárodných projektov. Jedným z takýchto projektov bol projekt 7RP ESTABLISH, ktorého výučbové materiály ako pre žiakov, tak aj pre učitelov poskytujú prostriedky na zavádzanie a využívanie bádatelských metód vzdelávania do výučby biológie, chémie a fyziky. Do tohto projektu bolo zapojených 11 krajín. Na Slovensku uplatnilo v praxi IBSE v sekundárnom vzdelávaní viac ako 40 vopred zaškolených učitelov prírodovedných predmetov. V priebehu implementácie bádatel’ských aktivít sa učitelia stretli s množstvom nejasností, ktoré vyústili do potreby navrhnút a zosúladit hodnotiace nástroje pre IBSE. Na ich tvorbe sa v rámci projektu SAILS podielajú tiež aj slovenskí uči-

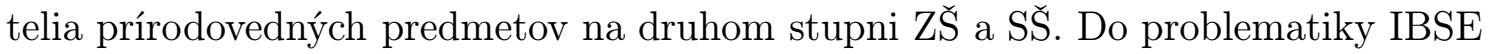
bolo na Univerzite Pavla Jozefa Šafárika v Košiciach a na ŠPÚ v Bratislave doteraz zaškolených približne 150 učitelov.

\section{VŠEOBECNÉ KRITÉRIÁ PRE HODNOTENIE ZRUČNOSTÍ NA ZÁKLADE PRÍPADOVÝCH ŠTÚDIÍ}

Vzhl’adom na to, že pri IBSE sa jedná o komplexné činnosti, kde pri vyšších stupňoch bádania žiaci realizujú samostatne viac krokov bádatel’ského cyklu, učitel' sa musí pred realizáciou konkrétnej bádatelskej aktivity rozhodnút, na ktorú zručnost̉ bude orientovat hodnotenie. V každom postupe sú klúčové momenty, ktoré sú vhodné na hodnotenie vybraných bádatel'ských zručností, pričom sa nemusia sledovat zručnosti vo všetkých krokoch bádatel’ského cyklu.

Ak chce učitel' maximalizovat úspech študentov, musí hodnotenie vnímat ako učebnú pomôcku počas vyučovacieho procesu a ako nástroj na určenie toho, či žiak danej problematike porozumel (Hung et al., 2010). Klúčová otázka zameraná na hodnotenie by mohla byt: „Čo je jeho základom - cielom?“ (Stobart, 2008). Všeobecne existujú na túto otázku dve odpovede: pomôct’ študentom v priebehu učenia sa alebo zistit, čo sa naučili v určitom čase (Harlen, 2013). Oba aspekty by mal byt učitel' schopný počas realizácie IBSE identifikovat’ a brat̉ do úvahy.

Ako dokazujú výsledky štúdií Freedmana (1997) a Prokopa (2007), používanie živých organizmov na hodinách biológie môže byt klúčovým faktorom zlepšenia postojov žiakov k predmetu biológia. Práve preto aj biologické bádatel'ské aktivity by mali byt zamerané aj na prácu so živým materiálom. Vzhl’adom na túto skutočnost sme pre naše štúdie zvolili aktivity, kde vo väčšine prípadov boli objektom bádania živé organizmy. Pri realizácii bádatelských aktivít je vhodné použit pre žiakov pracovné listy, aby žiaci boli vedení k písaniu si poznámok a otázok, ktoré rozvíjajú ich vlastné bádanie (Hung et al., 2010). Tento fakt sa potvrdil aj pri realizácií bádatel’ských aktivít učitelmi z praxe, najmä s mladšími a menej skúsenými žiakmi. Je dôležité, aby si žiaci osvojili vhodné spôsoby záznamu údajov a vyjadrenia výsledku, ako sú tabul'ky a grafy, a vedeli ich neskôr sami navrhnút.

V projekte SAILS vznikol na základe prípadových štúdií z aktivít pre predmety fyzika, chémia a biológia nástroj vo forme tabulky, ktorá pomáha učitelom formulo- 
vat vlastné kritériá hodnotenia zručností a odstupňovat jednotlivé úrovne ich zvládania žiakom. Na základe pilotovania viacerých navrhnutých spôsobov formatívneho hodnotenia zručností $\mathrm{v}$ praxi sa vopred premyslené odstupňovanie úrovní ukazuje ako praktická a l’ahko aplikovatelná pomôcka pre učitel'a. Najnižšiu zo štyroch úrovní predstavuje základná zručnost́, ktorú žiak následne rozvíja a upevňuje. Na najvyššej úrovni je schopný zručnost' samostatne rozšírit prepojením teoretických vedomostí s podstatou fundamentálnych javov. Hodnotenie je formulované pozitívne a popisuje aktuálny stav zvládnutia zručnosti konkrétnym žiakom. Je aditívne, to znamená, že $\mathrm{k}$ dosiahnutej úrovni zručnosti sa pridáva jeho vylepšenie novými prvkami. Žiak je so svojím hodnotením oboznámený v dialógu s učitelom počas činnosti. Zároveň dostáva informáciu, ako môže svoju zručnost̉ zlepšit, aby sa dostal o úroveň vyššie. Sumatívne hodnotenie vychádza z najlepšieho dosiahnutého výkonu žiaka v danej zručnosti po niekol'kokrát opakovanom formatívnom hodnotení počas klasifikačného obdobia. Ak žiak pozná kritériá jednotlivých úrovní, dokáže lepšie aj sám rozpoznat’, na ktorej úrovni zvláda zručnost’ a čo musí urobit, aby sa zdokonalil.

\section{KRITÉRIÁ HODNOTENIA NA KONKRÉTNYCH PRÍKLADOCH IBSE}

Počas implementácie IBSE realizovali učitelia vybrané bádatelské aktivity so žiakmi ZŠ a SŠ (4 členné skupiny žiakov) a následne navrhovali vhodné kritériá hodnotenia zručností žiakov. Nižšie uvádzame príklady dvoch aktivít a návrhy hodnotenia zručností, ktoré vychádzajú z prípadových štúdií.

Prvá aktivita bola zameraná na skúmanie intenzity fotosyntézy v alginátom imobilizovaných zelených riasach, pri rozličnej intenzite svetla, na základe farebnej zmeny indikátora $\mathrm{CO}_{2}$ (tab. 1). Realizovali ju učitelia na Z $\mathrm{Z}$ so žiakmi 6 . ročníka a na SS̆ so žiakmi 1. ročníka na dvoch za sebou radených vyučovacích hodinách. Tematické zameranie aktivity je súčastou ŠVP ISCED2 a ISCED3. Žiaci už poznali pojem a význam fotosyntézy na úrovni ZS̆, resp. SS̆. Žiaci 6. ročníka ZŠ rekapitulovali podstatu fotosyntézy v podobe riadeného rozhovoru, ktorý ich viedol k záverom, že ide o proces v tele rastliny, ked' anorganické látky (voda a oxid uhličitý) za prítomnosti svetla produkujú cukor, pričom sa uvolňuje kyslík. Ostatné organické látky sú produkované v bunkách premenou cukrov. Žiaci SS̆ boli schopní formulovat podstatu fotosyntézy samostatne. Učitelia poznajúc postup identifikovali tri klúčové zručnosti vhodné pre hodnotenie. Kedže šlo o riadené bádanie, žiaci mali samostatne naplánovat určité kroky postupu. Biologický materiál predstavovali alginátové guličky obsahujúce zelené riasy, ktoré pripravili žiaci podla návodu. Učitelia pri plánovaní experimentu sledovali, aký postup si žiaci zvolili pre rozdelenie biologického materiálu do troch vzoriek, aby dosiahli čo najpresnejší výsledok pokusu. Ďalej učitelia sledovali rozmiestnenie vzoriek do rôznej vzdialenosti od svetelného zdroja a odôvodnenie zvolenej vzdialenosti. Pri formulácii záverov sledovali uvažovanie žiakov.

Otázky učitela podporujúce bádanie pri tejto aktivite môžu byt nasledovné: „Ktoré pomôcky potrebuješ na rozdelenie alginátových guličiek do troch rovnakých nádob tak, aby bolo v každej nádobe rovnaké množstvo?", „Ako umiestniš jednotlivé vzorky do rôznej vzdialenosti od zdroja svetla tak, aby nastala čo najviditelnejšia farebná zmena indikátora?“. Tieto otázky je vhodné klást najmä mladším žiakom, nakol'ko ešte nemajú ucelené poznatky z danej problematiky ani dostatok skúseností so samostatným plánovaním pokusu. V 1. ročníku SŠ učitelia nepocitovali potrebu 
Tab. 1: Príklad návrhu podkladu pre hodnotenie niektorých zručností žiakov pri realizácii bádatelskej aktivity o intenzite fotosyntézy

\begin{tabular}{|c|c|c|c|c|}
\hline$\overline{\text { Zručnost' }}$ & Základ & Rozvoj & Upevnenie & Rozšírenie \\
\hline $\begin{array}{l}\text { Rozdelenie } \\
\text { materiálu }\end{array}$ & $\begin{array}{l}\text { navrhne } \\
\text { metódu } \\
\text { (váženie, } \\
\text { počítanie } \\
\text { guličiek, } \\
\text { meranie } \\
\text { objemu) }\end{array}$ & $\begin{array}{l}+ \text { zdôvodní } \\
\text { návrh metódy }\end{array}$ & $\begin{array}{l}+ \text { odborne } \\
\text { argumentuje } \\
\text { pre volbu } \\
\text { metódy }\end{array}$ & $\begin{array}{l}\text { + porovnáva } \\
\text { metódy (ich } \\
\text { rýchlost } \\
\text { a presnosté) }\end{array}$ \\
\hline $\begin{array}{l}\text { Rozmiestnenie } \\
\text { vzorky }\end{array}$ & $\begin{array}{l}\text { precízne } \\
\text { rozloží vzorky }\end{array}$ & $\begin{array}{l}+ \text { rozloží } \\
\text { vzorky } \\
\text { v primeraných } \\
\text { vzdialenosti- } \\
\text { ach } \\
\text { a zaznamená } \\
\text { čas pôsobenia } \\
\text { svetla }\end{array}$ & $\begin{array}{l}+ \text { uvádza } \\
\text { praktické } \\
\text { dôvody pre } \\
\text { odstupy } \\
\text { vzoriek (dĺžka } \\
\text { stola) }\end{array}$ & $\begin{array}{l}\text { + uvádza } \\
\text { dôvody } \\
\text { založené na } \\
\text { podstate } \\
\text { fotosyntézy }\end{array}$ \\
\hline $\begin{array}{l}\text { Zhotovenie } \\
\text { natívneho } \\
\text { preparátu }\end{array}$ & $\begin{array}{l}\text { položí riasy do } \\
\text { kvapky vody } \\
\text { na podložné } \\
\text { sklo a prikryje } \\
\text { krycím } \\
\text { sklíčkom }\end{array}$ & $\begin{array}{l}\text { + odhadne } \\
\text { optimálnu } \\
\text { vel'kost' } \\
\text { kvapky, odsaje } \\
\text { prebytočnú } \\
\text { vodu, preparát } \\
\text { je bez } \\
\text { vzduchových } \\
\text { bublín }\end{array}$ & $\begin{array}{l}+ \text { primerané } \\
\text { množstvo rias } \\
\text { v preparáte, } \\
\text { dajú sa dobre } \\
\text { pozorovat }\end{array}$ & $\begin{array}{l}\text { + manipuluje } \\
\text { s preparátom } \\
\text { (napr. pridá } \\
\text { činidlo, farbivo } \\
\text { a odsáva } \\
\text { z druhej } \\
\text { strany vodu) }\end{array}$ \\
\hline Nákres & $\begin{array}{l}\text { rozpozná } \\
\text { objekt }\end{array}$ & $\begin{array}{l}\text { + vystihne } \\
\text { charakteris- } \\
\text { tické znaky } \\
\text { objektu }\end{array}$ & $\begin{array}{l}\text { + zvláda } \\
\text { schematický } \\
\text { nákres, } \\
\text { primeraná } \\
\text { velkost, } \\
\text { mierka }\end{array}$ & $\begin{array}{l}+ \text { popíše } \\
\text { načrtnutý } \\
\text { objekt, } \\
\text { vysvetlí } \\
\text { detaily }\end{array}$ \\
\hline $\begin{array}{l}\text { Mikrosko- } \\
\text { povanie }\end{array}$ & $\begin{array}{l}\text { založí preparát } \\
\text { a zaostrí na } \\
\text { objekt }\end{array}$ & $\begin{array}{l}+ \text { mení } \\
\text { zväčšenie }\end{array}$ & $\begin{array}{l}+ \text { posúva } \\
\text { preparát, } \\
\text { chápe princíp } \\
\text { prevráteného } \\
\text { obrazu }\end{array}$ & $\begin{array}{l}\text { + ovláda aj } \\
\text { d’alšie funkcie } \\
\text { zariadenia } \\
\text { (napríklad } \\
\text { clona), chápe } \\
\text { fyzikálne } \\
\text { princípy }\end{array}$ \\
\hline
\end{tabular}


zamerat’ otázku na detaily, otázka napríklad znela: „Ako rozdelíte biologický materiál do troch rovnakých nádob, aby ste dosiahli v závere experimentu čo najpresnejší výsledok?" Niektorí žiaci síce pracovali precízne pri delení materiálu, zvažovali meranie objemu, váženie alebo či použit vo vzorkách rovnaký počet alginátových guličiek, ale vzdialenosti medzi vzorkami volili príliš malé. Iní žiaci zaznamenali čas pôsobenia svetla na vzorky a vzorky rozmiestnili do väčších vzdialeností, ale ani tie neboli ešte postačujúce na zaznamenanie dobre viditelných farebných zmien indikátora. Žiaci, ktorých zručnosti hodnotili učitelia pri tejto úlohe ako upevnené, boli schopní odôvodnit príčinu farebných zmien vo vzorkách na základe informácií o podstate indikátora $\mathrm{CO}_{2}$. Najlepšie zručnosti a schopnosti bádania prejavili tí žiaci, ktorí boli schopní vysvetlit podstatu experimentu na základe vedomostí o fotosyntéze. Súčastou aktivity realizovanej žiakmi SS̆ bolo zhotovenie natívneho preparátu rias a ich pozorovanie pod mikroskopom. Vyplnili tým čas, kým čakali na výsledok pokusu. Mladší žiaci potrebovali viac času na zaznamenanie postupu. Nasledujúca tabul'ka predstavuje ukážku učitel’mi formulovaných úrovní zvládania sledovaných zručností. Slúžila im ako podklad pre spätnú väzbu smerom k žiakom.

Ďalšou aktivitou v rámci pilotovania hodnotiacich nástrojov projektu SAILS bola aktivita o životných podmienkach bezstavovca - žižiavky obyčajnej (Porcellio scaber ${ }^{1}$. Bezstavovce žijúce v okolí ludských obydlí je téma ISCED2 v 6. ročníku, aktivita sa mohla realizovat’ v rámci štandardnej vyučovacej hodiny. Učitel' sa na predchádzajúcej hodine spýtal žiakov, čo si predstavujú pod pojmom žižiavka. Žiakom sa zdal tento názov neobvyklý. Tento pojem u nich vyvolal potrebu používat slová: pichl’avý (žihadlá), horúci (žíža), vypalovanie (žíhanie), dáždovka (z českého jazyka „žižala“) a d’alšie. Žiaci mali záujem toto slovo preskúmat, a tak ich domácou úlohou na d’alšiu hodinu, kedy bola aktivita realizovaná, bolo nájst̉ obrázok žižiavky na internete. Žižiavky sa často ukrývajú a majú fádnu farbu. Aj ked' na prvý pohlad, po hladaní obrázka žižiavky mali žiaci obavy ohladom velkosti a vzhladu tohto bezstavovca, ked' si uvedomili pri prvej manipulácii s nimi, aké sú malé, pracovali s nimi počas experimentu velmi ochotne. Väčšina žiakov si ich nikdy predtým nevšimla, no našli sa aj takí, ktorí po vyhladaní obrázka na internete sa rozpamätali, že tohto bezstavovca poznajú. V rozhovore riadenom učitelom žiaci formulovali predpoklad o tom, aké životné podmienky žižiavky uprednostňujú. Je pravdepodobné, že žiaci na základe vlastnej skúsenosti uvedú tmavé a vlhké prostredie. Niektorí žiaci, ktorí žižiavku nepoznali, argumentovali skôr pre suché slnečné prostredie. Bádatel'skú otázku si žiaci kládli sami počas rozhovoru s učitelom: „Ako by sme mohli dokázat,, či žižiavka uprednostňuje vlhké prostredie pred suchým a tmavé pred svetlým?". Žiaci pracovali so živým materiálom opatrne. Svoje postrehy si zaznamenávali do pracovných listov, ktoré v prvej časti obsahujú slová (teplo, tma, svetlo, ... ). Tie im pomohli formulovat predpoklad. K dispozícii bol pracovný list so stručným návodom na realizáciu pokusu. Žiaci pracovali v 4 členných skupinách a k dispozícii mali na výber rôzne pomôcky. Učitelia sledovali formuláciu výskumných otázok a hypotéz, ako aj plán experimentu vyjadrený jednotlivými žiakmi. Je rozdiel, či žiak vyjadrí svoj predpoklad „žižiavke sa sucho nepáči“ alebo ho formuluje „ak sa môžu žižiavky dostat na suchý alebo mokrý papier, pôjdu na mokrý". Tabul'ka 2 obsahuje úrovne hodnotených zručností pri aktivite o životných podmienkach žižiavok.

Spätnú väzbu poskytuje učitel’ pri formatívnom hodnotení žiakom priebežne vo forme dialógu, pričom si pomáha tabulkou kritérií na hodnotenie. Učitelia nemajú chápat kritériá naformulované v uvedených tabul'kách ako niečo dané alebo rigidné,

\footnotetext{
${ }^{1}$ Dostupné z http://www.experimentuj.eu/typ_experimentu/biologie/
} 
Tab. 2: Príklad návrhu podkladu pre hodnotenie niektorých zručností žiakov pri realizácii bádatelskej aktivity o životných podmienkach žižiavky obyčajnej

\begin{tabular}{|c|c|c|c|c|}
\hline Zručnost' & Základ & Rozvoj & Upevnenie & Rozšírenie \\
\hline $\begin{array}{l}\text { Kladenie } \\
\text { otázok }\end{array}$ & $\begin{array}{l}\text { Kladie otázky } \\
\text { ako } \\
\text { Vedia žižiavky } \\
\text { plávat?? Ako } \\
\text { dlho žijú? }\end{array}$ & $\begin{array}{l}\text { + otázky sa } \\
\text { týkajú } \\
\text { podmienok } \\
\text { prostredia, } \\
\text { v ktorom } \\
\text { žižiavky žijú. } \\
\text { (svetlo, teplo, } \\
\text { vlhkost) }\end{array}$ & $\begin{array}{l}+ \text { uvažuje } \\
\text { o možnom } \\
\text { vplyve } \\
\text { podmienok na } \\
\text { správanie } \\
\text { žižiavok }\end{array}$ & $\begin{array}{l}\text { + špecifikuje } \\
\text { podmienky } \\
\text { prostredia } \\
\text { (intenzita } \\
\text { svetla, } \\
\text { optimálna } \\
\text { vlhkost } \\
\text { a teplota) }\end{array}$ \\
\hline $\begin{array}{l}\text { Plánovanie } \\
\text { pokusu }\end{array}$ & $\begin{array}{l}\text { Plánuje } \\
\text { extrémne } \\
\text { podmienky, či } \\
\text { žižiavky } \\
\text { v niektorých } \\
\text { podmienkach } \\
\text { ne/prežijú } \\
\text { (vlhko alebo } \\
\text { sucho) }\end{array}$ & $\begin{array}{l}\text { + uvedomí si } \\
\text { vplyv } \\
\text { prostredia na } \\
\text { život žižiavky, } \\
\text { navrhne suché } \\
\text { a vlhké } \\
\text { prostredie - } \\
\text { porovnanie }\end{array}$ & $\begin{array}{l}\text { + navrhne aj } \\
\text { tmavé } \\
\text { a svetlé - } \\
\text { porovnanie }\end{array}$ & $\begin{array}{l}\text { + kombinuje } \\
\text { suché alebo } \\
\text { vlhké } \\
\text { s tmavým } \\
\text { alebo } \\
\text { svetlým - } \\
\text { porovnanie, } \\
\text { nový nápad na } \\
\text { pokus }\end{array}$ \\
\hline $\begin{array}{l}\text { Formulovanie } \\
\text { hypotézy }\end{array}$ & $\begin{array}{l}\text { Výrok } \\
\text { vychádza zo } \\
\text { zvedavosti, nie } \\
\text { je reálne } \\
\text { testovatelný }\end{array}$ & $\begin{array}{l}\text { + výrok } \\
\text { vychádza } \\
\text { z vlastnej } \\
\text { skúsenosti, je } \\
\text { reálne } \\
\text { testovatelný }\end{array}$ & $\begin{array}{l}+ \text { výrok } \\
\text { vychádza } \\
\text { z vedomostí } \\
\text { a skúseností }\end{array}$ & $\begin{array}{l}+ \text { zdôvodní, } \\
\text { prečo testovat } \\
\text { práve tento } \\
\text { výrok }\end{array}$ \\
\hline
\end{tabular}

môžu ich menit podla vlastnej skúsenosti. Väčšinou je výhodné formulovat ich de novo podla IBSE témy a zvolených klúčových zručností, ktoré sa v priebehu určitej aktivity dajú rozvíjat. Upriamit pozornost žiaka na to, kam má smerovat dalšie zlepšovanie jeho zručností, môže učitel' aj poukázaním na to, ako pracuje iný žiak, ktorý už dosiahol o stupeň vyššiu úroveň. Nie je vhodné od začiatočníka požadovat komplexnú rozšírenú zručnoste. Dôležité je, aby sa posunul z ovládania základu na rozvoj. V práci spolužiaka, ktorý je od neho len o stupeň lepší, môže mat́ vzor, ciel' sa mu nebude zdat taký nedosiahnutelný. Aj preto je práca v skupinách pri realizácii IBSE vítaná. Ak je čas, žiaci pri odchode z hodiny vyplnia jednoduchú kartu sebahodnotenia, kde odpovedajú na otázky typu: „Kto zo skupiny pracoval najaktívnejšie?“, „Bol tvoj nápad na realizáciu pokusu dnes použitý?“, „Potvrdil sa tvoj predpoklad?" Sebahodnotenie pritom slúži na uvedomenie si prínosu vlastnej práce k celkovému výsledku skupiny.

\section{ZÁVER}

S implementáciou aktivizujúcich metód do vzdelávacieho procesu je potrebné súčasne uplatňovat aj formatívne hodnotenie a z neho vychádzajúce sumatívne hodnotenie zručností súvisiacich s prírodovednou gramotnostou. V opačnom prípade je možné, že snaha aktivizovat žiaka bádatelsky orientovanou výučbou neprinesie po- 
žadované výsledky vo forme rozvoja zručností spadajúcich do tejto oblasti. Učitel' nebude schopný zmenu vo vzdelanosti žiaka zaznamenat a postupne sa vzdá pokusov o výučbu založenú na bádaní. Pri hodnotení zručností rozvíjaných v IBSE má učitel' otvorené možnosti, nakolko požiadavky a kritéria hodnotenia nie sú zatial' ani zd’aleka zadefinované. S prípadových štúdií, z ktorých sme vychádzali v tomto príspevku vyplýva, že nie je možné ani potrebné, aby učitel’ hodnotil všetky zručnosti vo všetkých krokoch bádatelského cyklu súčasne pri výučbe danej témy. Formulovat odstupňované hodnotiace kritériá pre každú zručnosț je náročné a sledovat̉ viac zručností súčasne je niekedy nemožné. Z prípadových štúdií projektu SAILS vyplýva, že je praktické rozlišovat a následne hodnotit štyri úrovne schopností a zručností, ktoré žiak preukazuje. O ich označovaní sa uskutočnilo mnoho diskusií na medzinárodnej úrovni. Navrhované hodnotiace nástroje sú nad’alej v štádiu pilotného overovania. Samozrejme majú byt len pomôckou a nie predpisom. Tvorba a upresňovanie kritérií a spôsob ich využitia je v kompetencii učitela, ktorý dokáže prispôsobit stupeň bádania danej vekovej kategórii žiakov a úrovni ich vedomostí. Pri práci s mladšími žiakmi si bádanie často vyžaduje použitie pracovných listov alebo náčrtov tabuliek či grafov, do ktorých žiaci podla učitelových očakávaní môžu zaznamenat' svoje výsledky, čo ulahčuje celý hodnotiaci proces. K zaznamenaným hypotézam, plánu na ich potvrdenie a záverom jednotlivých žiakov sa môže učitel' vrátit, ak chce znovu zhodnotit napredovanie žiakov.

\section{POĎAKOVANIE}

Tento príspevok vznikol s finančnou podporou projektu 7. rámcového programu SAILS (7th General Programme of EU, FP7/2007-2013 based on the no. 289085 agreement (http://sails-project.eu), d’akujeme vedeniu projektov a všetkým partnerom.

\section{LITERATÚRA}

Chin, Ch. \& Chia, L. (2005). Problem-Based Learning: Using Ill-Structured Problems in Biology. Project WorkWiley InterScience. Dostupné z http://www.interscience.wiley.com

Chmurová, J. \& Juricová, I. (2011). Výskumne ladená koncepcia prírodovedného vzdelávania v praxi (470-477). Prešov: MVEK.

Edelson, D. C., Gordin, D. N., \& Pea, R. D. (1999). Addressing the challenges of inquiry-based learning through technology and curriculum design. The Journal of the Learning Sciences, $8(3$ \& 4), 391-450.

Erdogan, T. \& Senemoglu, N. (2014). Problem-based Learning in Teacher Education: Its Promises and Challenges. Procedia - Social and Behavioral Sciences, 116, 459-463.

Freedman, M. P. (1997). Relationship among laboratory instruction, attitude toward science, and achievement in science knowledge. Journal of Research in Science Teaching, $34(4), 343-357$.

Harlen, W. (2013). Assessment \& Inquiry-Based. Science Education: Issues in Policy and Practice. Global Network of Science Academies (IAP) Science Education Programme.

Held, L., Žoldošová, K., Orolínová, M., Juricová, I. \& Ktuláková, K. (2011). Výskumne ladená koncepcia prírodovedného vzdelávania. Trnava: Trnavská Univerzita v Trnave. 
Hung, P. H., Lin, Y. F., \& Hwang, G. J. (2010). Formative Assessment Design for PDA Integrated Ecology Observation. Educational Technology \& Society, 13 (3), 33-42.

Introduction to Formative Assessment, (2006). In Assessing for Learning Facilitator's Guide. Exploratorium. Dostupné z

http://www.exploratorium.edu/ifi/workshops/assessing/one/guide.html

Olson, S. \& Loucks-Horsley, S. (Eds.). (2000). Inquiry and the National Science Education Standards: A guide for teaching and learning. Washington, DC: National Research Council.

Kimáková, K., Lešková, A. \& Slepáková, I. (2014). Formativne hodnotenie vo výučbe biológie založenej na bádaní. Príspevok prezentovaný na medzinárodnej vedeckej konferencii Výchova a vzdelávanie 2014: Kontexty vzdelávania a výchovy v súčasnej perspektíve, Košice.

Llewellyn, D. (2009). Facilitator's guide: inquire within, second edition: implementing inquiry-based science standards in grades 3-8. Thousand Oaks, CA: Corwin Press.

Minstrell, J. \& van Zee, E. H. (2000). Inquiry into inquiry learning and teaching in science. Washington, DC: American Association for the Advancement of Science.

Papáček, M. (Ed.). (2010). Didaktika biologie v Česke republice 2010 a badatelsky orientované vyučováni (DiBi 2010). Sborník přispěvků semináře, 25. a 26. března 2010, Pedagogická fakulta Jihočeské univerzity v Českých Budějovicích. Dostupné z http://www.pf.jcu.cz/stru/katedry/bi/DiBi2010.pdf

Schmidt, H. G. (1983). Problem based learning: rationale and description. Medical Education, 17, 11-16.

Stobart, G. (2008). Testing Times. The uses and abuses of assessment. London: Routledge.

Šiškovič, M. \& Toman, J. (2014). PISA 2012: výsledky Slovenska v kocke. Inštitút vzdelávacej politiky. Ministerstvo školstva, vedy, výskumu a športu SR. Dostupné z https://www.minedu.sk/data/att/6077.pdf

Wenning, C. J. (2005). Levels of inquiry: Hierarchies of pedagogical practices and inquiry processes. Journal of physics teacher education, 2(3), 3-12.

IVANA SlePÁKovÁ, ivana.slepakova@upjs.sk

KATARÍnA KimÁKOvÁ, katarina.kimakova@upjs.sk

Univerzita Pavla Jozefa Šafárika, Prírodovedecka fakulta

Oddelenie didaktiky biológie

Mánesova 23, 04001 Košice, Slovenská republika 